\title{
血液透析患者における基礎疾患の違いによる免疫機能の検討
}

\author{
桑原守正松下和弘吉永英俊 安芸 雅 史 \\ 藤 崎 伸太徳田 倫 章* \\ 藤崎病院泌尿器科 九州大学泌尿器科*
}

key words：血液透析，囊胞腎，Tリンパ球サブポピュレーション，リンパ球幼若化反応，NK 細胞

〈要旨〉

慢性腎不全の発症においてその背景として免疫の関与がほとんど考えにくいとされている囊胞腎 (PCK) が原因で 透析を施行している患者 10 名（男 7 名, 女 3名), 慢性糸球体腎炎を基礎疾患として透析中の患者 42 名（男 31 名, 女 11 名）を短期透析（2 年未満, 24 名）と長期透析（9 年以上, 18 名）に分けて, Tリンパ球サブポピュレーショ ン, リンパ球幼若化反応 (PHA, Con A, PWM 反応) および NK 活性・IL-2 産生能を検討した。

1) Tリンパ球サブポピュレーションにおいて OKT3, OKT4 陽性細胞率は PCK 透析群 $\left(\mathrm{HD}_{\mathrm{P}}\right)$ で健常者に比し有 意に高かった $(p<0.05)$. 2 2 ) リンパ球幼若化反応は全ての群で良好な反応を示した。 3 ) NK 活性は慢性腎炎透析群 において短期・長期の両群 $\left(H D_{S} \cdot H D_{L}\right)$ において健常者に比べ有意に低かった $(p<0.01)$. 一方, $H D_{\mathrm{P}}$ 群では正常 範囲内であった。 IL-2 産生能は全ての群で異常は見られなかった.

以上より, 囊胞腎透析群では他の基礎疾患を有する透析患者とは免疫能が異なる可能性が推測された. 今後, $\mathrm{HD}_{\mathrm{P}}$ 群 の個々の患者において透析導入早期（ 0 ～2 年）の免疫能の状態および経年変化を検討していくことが，より正確な 免疫状態を知るうえで重要であると考えられた。

\section{Immune response in hemodialysis patients with various underlying diseases}

Morimasa Kuwahara, Kazuhiro Matsushita, Hidetoshi Yoshinaga, Masashi Aki, Nobuta Fujisaki, Noriaki Tokuda*

Department of Urology, Fujisaki Hospital ; Department of Urology, Faculty of Medicine, Kyushu University*

Ten patients ( 7 males and 3 females) undergoing dialysis for polycystic kidney (PCK), in which it is considered almost impossible for immunity to participate as a background factor in the onset of chronic renal insufficiency, and 42 dialysis patients ( 31 males and 11 females) whose underlying disease was chronic glomerular nephritis, were divided into a short-term dialysis group (less than 2 years ; 24 patients) and a long-term dialysis group (9 years or more; 18 patients). T lymphocyte subpopulations, lymphocyte transformation response (PHA, Con A, PWM reaction), NK activity and IL-2 productivity were investigated in these groups.

1) With regard to the $T$ lymphocyte subpopulations, the rates of OKT3- and OKT4-positive cells were significantly $(p<0.05)$ higher in the group undergoing dialysis for PCK $\left(H D_{P}\right)$ than in healthy subjects. 2$)$ All groups showed favorable lymphocyte transformation. 3 ) NK activity was significantly $(p<0.01)$ lower in the short- and long-term chronic nephritis dialysis groups $\left(\mathrm{HD}_{\mathrm{s}}, \mathrm{HD}_{\mathrm{L}}\right)$ than in healthy subjects. On the other hand, $\mathrm{NK}$ activity was within normal range in the $\mathrm{HD}_{\mathrm{P}}$ group. IL-2 productivity was normal in all groups.

The above results suggest that immunological competence in $\mathrm{HD}_{\mathrm{P}}$ is different from that in dialysis patients with other underlying diseases. It appears to be important to investigate the condition of immunological competence early in dialysis ( $0 \sim 2$ years after onset) and to examine annual changes in immunological competence in individual patients with $H D_{\mathrm{P}}$.

桑原 守正 藤崎病院泌尿器科 $\overline{\mathbf{T}} 847$ 唐津市栄町 2576 (0955-72-5125)

〔受付: 平成 4 年 4 月 13 日, 受理：平成 4 年 10 月 6 日〕 


\section{緒言}

血液透析患者に打ける免疫不全状態に関しては多数の 報告があるが，その免疫関連細胞の異常については報告 者により異なることも多い。これは慢性腎不全の基礎疾 患が多岐にわたっていることと，血液透析における透析 器材などの諸条件を無視して，すべてを同一のものとし て諭じているためと考えられる。一方, 腎不全の発症に ほとんど免疫の関与が考えにくいとされる囊胞腎 (PCK) が原因で透析中の患者を対象にしてその免疫能 を検討したものは少ない、をこで，今回我々は透析条件 をほほ同一として PCK を中心に免疫関連細胞を検討し たので若干の文献的検討を加え報告する。

\section{対象}

対象（表 1) 络，本院にて週 3 回の維持透析学施行中 で,ダイアライザーは蒸気滅菌のものを使用している患 者に限定し，他の透析器材もすべて同一とした。

PCK が基礎疾患で血液透析（3〜8年）を受けている 者 $\left(\mathrm{HD}_{\mathrm{P}}\right)$, 他仗すべて慢性系球体腎炎 $(\mathrm{CGN})$ が原疾患 として透析中で, 透析歴が 2 年末満の短期透析群 $\left(\mathrm{HD}_{\mathrm{s}}\right)$ と 9 年以上の長期透析群 $\left(\mathrm{HD}_{\mathrm{L}}\right)$ に分U, 健康成人 7 名 を刘照群とした。

なおすべての対象者に邨いて抗 ATLA（成人Tリンパ 球性白血病）抗体杇よび $\mathrm{HB}_{\mathrm{S}}$ 抗原が陰性であることを 条件とした。

\section{方法}

検查に用いた血液は各々透析開始直前に採血し, BML 社に依頼し以下の項目を検討した。

1.末松血Tリンパ球サブポピュレーション（PBL phenotype)

$\mathrm{OKT}^{+}(\mathrm{CD} 3), \mathrm{OKT}^{+}(\mathrm{CD} 4), \mathrm{OKT}^{+}(\mathrm{CD} 8), 4^{+} /$ $8^{+}, \mathrm{OKIal}^{+}$(class II)

2、リンパ球幼若化反応

Phytohemagglutinin (PHA), concanavalin A (Con A) および pokeweed mitogen (PWM) 刺激によるリン
パ球幼若化反応

3. Natural Killer (NK) 活性, Interleukin-2 (IL-2) 産生能

結果

以下に記す検查成績の数值は mean士SD で表し, 有意 差検定にはWilcoxon 検定を用いた。

1.Tリンパ球サブポピュレーション（表 2)

1) OKT3 陽性細胞比率 (58.6 89.0\%)

成熟したすべてのT細胞に存在するとされる OKT3 はT細胞の抗原レセプターに関係した抗原である。各群 で健常者に比し全体的に高く，特に $\mathrm{HD}_{\mathrm{P}}$ 群では有意に 高かった $(\mathrm{p}<0.05)$.

2） OKT4 陽性細胞比率 $(31.7 \sim 52.1 \%)$

OKT4 陽性細胞飞娘へルパーのほか, サプレッサーの インジューサー，クラスII MHCを認識するキラーTリ ンパ球が含まれている，OKT3 と同様にす心゙ての透析群 で高く，特に嫼胞繁透析群 $\left(\mathrm{HD}_{\mathrm{P}}\right)$ で有意に高加った $(\mathrm{p}<0.05)$.

3） OKT8 陽性細胞比率（17.4～43.0\%）

表 1 対象

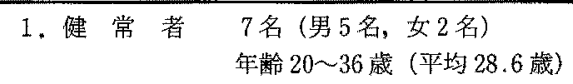

2. 霬胞腎基礎疾患とする逶析患者 $\left(\mathrm{HD}_{\mathrm{p}}\right)$ 10 名（男7名，女 3 名） 年齢 $48 \sim 62$ 藏（平均 52.5 藏） 透析歴 $4.5 \sim 10.2$ 年 (平均 8.5 年)

3. 慢性糸球体腎炎を基碟疾惠とする透析患者 42 名（男 31 名，女 11 名） 年齢 16 71 歳（平均 46.8 歳）

1) 短期透析 (HDs) 2 年末満（透析歴 $1.2 \sim 1.9$ 年 平均 1.7 年) 24 名 (男 18 名, 女 6 名) 年齢 16 65 歲 (平均 51.2 歳)

2) 長期透析 $\left(\mathrm{HD}_{\mathrm{L}}\right) 9$ 年以上 (透析歴 9.1 14.2 年 平均 11.8 年) 18 名（男 13 名，女 5 名） 年齢 $28 \sim 71$ 歳 (平均 61.2 歳)

表 2 HD 患者のTリンパ球サブポピュレーション

\begin{tabular}{|c|c|c|c|c|c|}
\hline \multirow[b]{2}{*}{ 対 象 } & \multicolumn{5}{|c|}{ PBL phenotype (\%) } \\
\hline & $\begin{array}{l}\mathrm{OKT}^{+} \\
\text {(CD3) }\end{array}$ & $\begin{array}{l}\text { OKT4* } \\
\text { (CD4) }\end{array}$ & $\begin{array}{c}\mathrm{OKT}^{+} \\
\text {(CD8) }\end{array}$ & $4^{+} / 8^{+}$ & $\begin{array}{c}\text { OKIa1 }^{+} \\
\text {(class II) }\end{array}$ \\
\hline $\begin{array}{l}\text { 健常者 } \\
(\mathrm{n}=7)\end{array}$ & $69.1 \pm 5.2$ & $45.6 \pm 5.5$ & $23.2 \pm 6.8$ & $2.2 \pm 0.8$ & $17.8 \pm 2.4$ \\
\hline $\begin{array}{c}H D_{p} \\
(n=10)\end{array}$ & $78.1 \pm 5.4^{*}$ & $58.1 \pm 8.9^{*}$ & $20.6 \pm 7.3$ & $3.3 \pm 1.8$ & $16.8 \pm 6.3$ \\
\hline $\begin{array}{c}\mathrm{HD}_{\mathrm{S}} \\
(\mathrm{n}=24)\end{array}$ & $63.5 \pm 5.7$ & $40.2 \pm 8.3$ & $23.6 \pm 10.2$ & $2.5 \pm 1.1$ & $20.2 \pm 4.6$ \\
\hline $\begin{array}{c}\mathrm{HD}_{\mathrm{L}} \\
(\mathrm{n}=18)\end{array}$ & $66.9 \pm 9.0$ & $44.8 \pm 9.1$ & $20.2 \pm 7.6$ & $3.0 \pm 1.1$ & $21.9 \pm 6.8$ \\
\hline
\end{tabular}


表 3 リンパ球幼若化反応

\begin{tabular}{|c|c|c|c|}
\hline & Con A & PHA & PWM \\
\hline $\begin{array}{l}\text { 健常者 } \\
(\mathrm{n}=7)\end{array}$ & $63,975 \pm 3,652$ & $116,459 \pm 41,685$ & $36,698 \pm 24,677$ \\
\hline $\begin{array}{c}\mathrm{HD}_{\mathrm{P}} \\
(\mathrm{n}=10)\end{array}$ & $60,618 \pm 36,252$ & $105,651 \pm 53,894$ & $34,861 \pm 20,731$ \\
\hline $\begin{array}{c}\mathrm{HD}_{\mathrm{S}} \\
(\mathrm{n}=24)\end{array}$ & $64,690 \pm 30,839$ & $88,529 \pm 48,664$ & $36,635 \pm 17,610$ \\
\hline $\begin{array}{c}\mathrm{HD}_{\mathrm{L}} \\
(\mathrm{n}=18)\end{array}$ & $82,460 \pm 26,755$ & $90,556 \pm 55,560$ & $47,014 \pm 19,953$ \\
\hline
\end{tabular}

${ }^{3} \mathrm{H}$-Thymidine uptake (cpm)

OKT8 陽性細胞にはサプレッサーとクラス I (MHC) を認識するキラーTリンパ球が含まれている，各群とも 正常範囲内であり有意の差はなかった。

4) OKT4 と OKT8 陽性細胞比 (0.5〜2.3\%)

OKT4 と OKT8 の比率はさまざまの病的状態で変化 する. AIDSでは OKT4 が著減し OKT4/OKT8 比が低 下することが有名である。 $4^{+} / 8^{+}$は健常者と比べ有意の 差はなかった。

5 ） OKIa-1 陽性細胞比率 (3.9〜23.9\%)

Ia 抗原（クラス II）を表出しているTリンパ球の增加 は Tリンパ球が活性化されていることを示唆し，免疫系 の活動性の指標として応用できる， $\mathrm{HD}_{\mathrm{S}} \cdot \mathrm{HD}_{\mathrm{L}}$ 群で高い 傾向にはあるが有意の差は認められない。

2.リンパ球幼若化反応（表 3 ）

PHA および Con A 刺激によるリンパ球幼若化反応は Tリンパ球の総合的機能評価に用いられている.

\section{1) Con A response}

各群間に明らかな差はなく全体的には良好な反応であ る.

2) PHA response

$\mathrm{HD}_{\mathrm{P}}$ 群で良好で，CGN 短期透析群 $\left(\mathrm{HD}_{\mathrm{S}}\right)$ では健常 者群に比しやや悪いが有意差はない.

3) PWM response

PWM 刺激は $\mathrm{T}$ リンパ球を介して B リンパ球を幼若化 させる. 各群とも良好な反応を示した。

3. IL-2 産生能 (表 4 )

活性化された $\mathrm{T}$ 細胞が産生し， T細胞の増殖をもたら す物質として知られておう，さまざまの生物活性を有し ている。各群に扔いて良好で, 特にCGN 長期透析群 $\left(\mathrm{HD}_{\mathrm{L}}\right)$ では産生が亢進しているが有意の差はない.

4. NK 活性（表 4)

腫瑒細胞・ウィルス感染細胞・移植細胞などの破壊に 関与するといわれている Natural Killer (NK) 細胞の 活性をみた. CGN 透析群では $\mathrm{HD}_{\mathrm{S}} ・ \mathrm{HD}_{\mathrm{L}}$ 群ともに健常 者に比し有意に低く $(\mathrm{p}<0.01), \mathrm{HD}_{\mathrm{P}}$ 群では穴進してい
表 4 IL-2 産生能および NK 活性

\begin{tabular}{ccccc}
\hline & $\begin{array}{c}\text { 健常者 } \\
(\mathrm{n}=7)\end{array}$ & $\begin{array}{c}\mathrm{HD}_{\mathrm{P}} \\
(\mathrm{n}=10)\end{array}$ & $\begin{array}{c}\mathrm{HD}_{\mathrm{S}} \\
(\mathrm{n}=24)\end{array}$ & $\begin{array}{c}\mathrm{HD}_{\mathrm{L}} \\
(\mathrm{n}=18)\end{array}$ \\
\hline $\begin{array}{c}\text { IL-2 産生能 } \\
\text { (Unit) }\end{array}$ & $23.7 \pm 23.4$ & $29.4 \pm 24.0$ & $29.9 \pm 26.8$ & $69.2 \pm 54.3$ \\
$\begin{array}{c}\mathrm{NK} \text { 活性 } \\
(\%)\end{array}$ & $20.1 \pm 9.2$ & $28.5 \pm 20.6$ & $12.0 \pm 9.0^{*}$ & $16.7 \pm 11.2^{*}$ \\
\hline
\end{tabular}

${ }^{*} \mathrm{p}<0.01$ (vs normals)

たが有意の差はない.

\section{考察}

透析患者に招ける免疫能に関しては数多くの報告 ${ }^{1-31}$ があり,そのほとんどが低下しているというものである. そしてその適度な免度不全状態が腎移植には比較的好都 合に，また感染症 ${ }^{4}$ ・悪性腫瘍の発生 ${ }^{5 \sim 7} に$ に不利に働く と解釈されている。しかし一方，透析患者においてはい われているほどには強い免疫不全状態にはなく，むしろ 正常範囲にあるとする報告も一部には見られる。

透析年数, 年齢, 性差, 輸血の有無, ウィルス感染の 有無, 蛋白摂取量との関連扔よび透析器材などとの関わ りなどについて詳しく調べられている ${ }^{8 \sim 10}$ が，そのいず れもが種々の免疫学的背景を持った疾患を同一のものと して論じているためと推測される。そこで今回，我々は 腎不全の発症に免疫の関与が考えにくい PCK を中心に 検討を加えた。

諸家の報告をみても，透析患者に招けるТリンパ球サ ブポピュレーションは一定していない，我及の検討した PBL phenotype はすべて正常範囲内であり，その中で $\mathrm{HD}_{\mathrm{p}}$ 群で $\mathrm{OKT} 3 ・ \mathrm{OKT} 4$ 陽性細胞の両方が有意に高 かった $(\mathrm{p}<0.05) . \mathrm{OKT} 8$ は高くないことより OKT3 の上昇は OKT4 の上昇によるものと考えられる.しかし ながらこの結果をもって PCK 群も含めて透析患者にお ける免疫反応が正常であるとはいえない，大崎らの一連 の報告 ${ }^{11 \sim 13)}$ にみられるように生体の，特に慢性腎不全患 者における免疫不全は免疫関連細胞の比率や数のみなら ずその相互作用も含めて総合的に決定されるべきものと 考えられる。

リンパ球の mitogen に対する幼若化反応では, Con $\mathrm{A} \cdot \mathrm{PHA}$ 刺激による透析患者のリンパ球反応は低下する という報告が多く，特に PHA 反応は透析導入より 3 年 以上が経過した安定透析時期からもな扔陰性率がより高 くなるといわれておうう ${ }^{14,15)}$ ， T細胞機能の障害があるこ とが示唆されている。我々の検討では PHA 反応におい て有意の差はなかったが, $\mathrm{HD}_{\mathrm{s}}$ 群で若干反応が悪く, $\mathrm{HD}_{\mathrm{p}}$ 群では良好な反応を示した。免疫に関連した uremic toxin ${ }^{4)}$ が PCK 群では他の基礎疾患を有する透 析患者とは異なるのであろうか. BUN, クレアチニン濃 
度は各群間においてて有意な差はなく，その詳細は不明で ある。

リンパ球幼若化反応を阻害する物質は透析患者の血清 中に存在して抢り, かつ透析性 ${ }^{16,17)}$ といわれている, 今回 これらも検討すべき課題であったかと反省させられた。

PWM 刺激によるリンパ球反応は, 今回の我々の検討 では Sengar ら ${ }^{18)}$ の報告と一致して全ての群で健常者と の間に明らかな相違はなかった。この反応に関してはい まだ一定の見解は得られていない.これは PWM 反応が 主としてBリンパ球の機能を反映しているためかも知礼 ない.

これら一連の検查は非特異的反応であるが簡便で再現 性もよいためによく利用されるが，PHA 皮内テストと 血清アルブミン值との関連 ${ }^{19)}$, 亜鉛欠乏による遅延型皮 膚反応の抑制 ${ }^{20)}$ などが報告されて㧍り判定には注意が必 要である.最近, DNCB (2, 4-dinitro-1-chlorobenzene) で皮唐を感作する方法 ${ }^{21)}$ が注目されているが, 真に感作 されたか否かの問題や，さらに貧血との相関がある ${ }^{22} こ$ とを念頭に扔き，常に全身状態を把握しながら考えるこ とが重要である.

ウィルス感染や腫崵に対する生体防御を担うとされて いる $\mathrm{NK}$ 細胞による $\mathrm{NK}$ 活性，抢よびこれに連動する IL-2 産生能は Badger ら ${ }^{23}$ によると透析患者では低下 しており，Matas ら゙は悪性新生物との関連を報告して いる. 我々の検討では NK 活性が PCK 群では元進して おり，CGN 透析群では有意に低下していた。このことよ り同じ透析患者でも基礎疾患の違いにより生体の防御能 が異なる可能性が示唆された。透析患者の悪性腫崵の発 症に関しては, PCK では悪性腫場の発生率が透析とは無 関係に高いこと，透析期間よりも年齢の関与が大きいこ と, analgesic nephropathy では尿路悪性腫場が多い24) ことなどより，透析患者における悪性腫瘍の発生は，細 胞性免疫異常のみで論じることは危険であると考えられ る.

以上, PCK 群は何らかの要因で細胞性免疫の低下が起 こりにくい可能性が示唆されるが, 透析導入早期 $(0 \sim 2$ 年)の免疫能の状態を検討しておらず推測の域を出ない. 今後, PCK 透析患者の個々に敌いて透析導入短期におけ る免疫能抢よびその経年変化をさまざまな角度から検討 してゆくことが重要であると思えた。

\section{結語}

血液透析患者における細胞性免疫をその基礎疾患が囊 胞腎 (PCK) である者と, 慢性系球体腎炎 (CGN) の者 とに分けて検討し次の結果を得た。

1. $\mathrm{PCK}$ 透析患者は Tリンパ球サブポピュレーショ ンにおける OKT3, OKT4 陽性細胞比率が健常者に比べ
有意に高かった $(\mathrm{p}<0.05)$.

2.リンパ球幼若化反応は全ての群で健常者との間に 明らかな差はなく良好な反応であった。

3. NK 活性は CGN 透析の両群で健常者に比し有意 に低く（p<0.01），PCK 透析群では正常範囲内であっ た。

囊胞腎を基礎疾患とする透析患者では何らかの要因に より免疫能は有意には低下しないのではないかというこ とが推察された。

\section{文献}

1) Kurz P, Köhler H, Meuer S, Hütteroth T, Meyer $\mathrm{H}$ : Impaired cellular immune responses in chronic renal failure: Evidence for a $\mathrm{T}$ cell defect. Kidney Int $29:$ 1209-1214, 1986

2) Bradely SB, Jeffrey LC, James EN, Francis JC, Edward SK, Gray RB, William HA : Analysis of immune status of homodialyzed adults : Association with prior transfusions. Kidney Int $26: 436$ $-443,1984$

3) Weeke B, Weeke E, Bendixen G: The variation in twenty-one serum protein before and after renal transplantation. Acta Med Scand 189 : 113 $-118,1971$

4）稲本 元：尿毒症における免疫不全と結核症. 透析 会誌 $12 ： 21-36,1979$

5) Ota K, Yamashita N, Suzuki T, Agishi $T$ : Malignant tumors in dialysis patient. A nation wide survey. Proc EDTA 18:724-730, 1981

6）山下賀正：消化器の疾患. 透析療法に颃ける合併症 (大野丞二編)，p 55-75，日本メディカルセンター， 東京, 1981

7) Matas AJ, Simmons RL, Kjellstrand CM, Buselmeier TJ, Najarian JS : Increased incidence of malignancy during chronic renal failure. Lancet i : 883-886, 1975

8）大崎和弥，尾辻義人：透析患者に抢けるリンパ網内 系および免疫関連細胞の構成. 臨床透析 $2: 1965-$ 1969, 1986

9) Kaplan J, Sarnaik S : Transfusion-induced immunologic abnormalities not related to AIDS virus. N Engl J Med 313 : 1227, 1985

10) Marsshall C, Shimizu E, Smith KM, Dolovich J : Ethylene oxide allergy in a dialysis center: prev. alence in hemodialysis and peritoneal dialysis populations. Clin Nephrol 21 : 346-349, 1984 
11) Osaki K, Otuka H, Uomizu K, Harada R, Otsuji $\mathrm{Y}$, Hashimoto S : Monocyte-mediated suppression of mitogen responses of lymphocytes in uremic patients. Nephron $34: 87-92,1983$

12）大崎和弥生, 大塚秀行, 魚水憲二, 森田隆久, 宮沢 修三，原田隆二，尾辻義人，橋本修治：慢性腎不全 患者に扔ける液性免疫能。日腎誌 $25 ： 993-1001$, 1983

13) Osaki K, Uomizu K, Otsuka H, Morita T, Uemura S, Harada R, Otsuji Y, Hashimoto S : Suppressed immune responsiveness in chronic renal failure. 透 析会誌 $19: 75-81,1986$

14）沼田 明, 田村雅人，秋山欣也，秋山昌範，川西泰 夫，湯浅 誠，今川章夫：慢性透析患者における PHA 皮内テスト, PPD 皮内テストの経年変化の検 討. 透析会誌 $21: 455-458,1988$

15）柄沢英一, 浅野美智雄, 石田仁男, 黒岡雄二, 横山 博美, 高山智之: 慢性腎不全患者の免疫能経年変化 の検討。透析会誌 $19: 711-714,1986$

16) Newberry WM, Sanford JP : Defective cellular immunity in renal failure: Depression of reactivity of lymphocytes to phytohemagglutinin by renal failure serum. J Clin Invest $50: 1262$ $-1271,1971$

17) Ludwig H, Stummvoll HK, Scherenthaner G : Mitogen-induced lymphocyte transformation during haemodialysis. Proc EDTA 16 : 711-713, 1979
18) Sengar DPS, Rashid A, Harris JE : In vitro reactivity of lymphocytes obtained from uraemic patients maintained by haemodialysis. Clin Exp Immunol $21: 298-305,1975$

19）前林浩次, 湯浅 誠, 滝川 浩, 今川章夫：泌尿器 科領域における Phytohemagglutinin 皮内テスト. 臨泌 $32 ： 1049-1053,1978$

20) Antoniou LD, Shalhoub RJ, Schechter GP : The effect of zinc on cellular immunity in chronic uremia. Am J Clin Nut 34 : 1912-1917, 1981

21）坂口泰弘，石橋純子，西川 潔，三上理一郎，白浜 禧宜: 慢性血液透析患者に扔ける免疫皮膚反応 -DNCB 反応と PPD 反応一。腎と透析 $19 ： 1287$ 1291, 1986

22) Giacchino F, Alloatti S, Quarello F, Bosticardo GM, Giraudo G, Piccoli G: The immunological state in chronic renal insufficiency. Int J Art Org 4:237-247, 1982

23) Badger AM, Bernard DB, Idelson BA, Cooperband SR: Depressed spontaneous cellular cytotoxicity associated with normal or enhanced antibody-dependent cellular cytotoxicity in patients on chronic haemodialysis. Clin Exp Immunol 45 : 568-575, 1981

24) Jacobs $C$, Reach $I$, Decoulet $P$ : Cancer in patients on hemodialysis. N Engl J Med 300 : 1279-1280, 1979 